\title{
THE HISTORY OF THE FLANNEL BINDER AND CHOLERA BELT
}

\author{
BY \\ E. T. RENBOURN, B.Sc., M.D., M.R.G.P. \\ From the Directorate of Physiological and Biological Research, Clothing and Stores \\ Experimental Establishment, Ministry of Supply
}

\section{INTRODUCTION}

BELTS and girdles have been worn since time immemorial, and there is evidence that the earliest form of clothing in hot climates was a hip girdle from which objects of utility were hung. In early times the diaphragm was believed to divide the pure upper half from the impure lower half of the body. The biblical Jews often wore a girdle to accentuate this division, and girding the loins was also preparation for activity and for war. In ancient Egypt women sometimes wore a hip girdle as the sole garment, and the men a pleated belt or skirt. Greek warriors wore belts about five inches in breadth, wide in front and tapering at the back, of metal or leather and padded with wool. These belts or 'zoneae' were sometimes the only body cover used in battle. The Roman soldier wore a 'cingulum' or girdle with three protective lappets.

Reference will be made periodically to the cummerbund (Persian: Kamberband, loin cloth) or ornamental waist-sash worn, usually, outside the clothing. The use of the word by English writers dates back to at least the fourteenth century.

The ancient Egyptians wore linen out of religious considerations and burial in woollen garments was forbidden. In Babylon and elsewhere wool was, however, the material normally used. Whether the Greeks and Romans and later European people used wool because of its peculiar properties or because of economic considerations is not always clear. Religious factors, and the fear of cold with the consequent obstruction of (insensible) perspiration, were undoubtedly important factors leading to overburdening the body with clothing, a habit so common from the Dark Ages onwards. The Egyptians, Greeks and Romans had, however, a much more rational attitude to body hygiene, believed in the virtue of a cool skin and wore light clothing.

The history of the waistcoat and its predecessors-the placard and stomacher-is closely interwoven with the vagaries of fashion, but these items of clothing were often used by both sexes to repel cold or damp from the body. In I666 Samuel Pepys recorded: 'I have of late taken much cold by washing my feet and going in a thin silke waist-coate and without any other coate over it, and open breasted.' 


\section{E. T. Renbourn}

\section{THE GHILLED BODY AND FLANNEL GARMENTS TO THE EIGHTEENTH GENTURY}

In I 707 Jeremiah Wainewright wrote on flannel garments as follows: 'The most certain and constant effect of wearing flannel is to make a free and plentiful perspiration, ${ }^{*}$ which tho' it be attended with great advantage (according to Sanctorius) when moderate, yet when excessive nothing is more pernicious. I was perswaded', he continued, 'to wear Flannel next my Skin some ten Years ago for a severe Cough that I had got, of which, I think, I received some advantage, but after I had worn it a Year or two, I found it troublesome and prejudicial to my Health; it made me so exceedingly tender that I was not able to bear the least cold.' John Quincy ( I 720) was a believer in a cool skin. Thus he commented on the 55th Aphorism of Sanctorius: 'There can hardly therefore be any greater Error committed than for weak People to load themselves with garments which is very customary: and to do it, as they say, to avoid catching Cold, is the only Way to expose themselves to be disordered thereby.' With reference to the prevention of diarrhoea, Richard Towne ( 1726 ) noted that 'those who are subject to habitual Looseness may receive great Benefit by wearing Flannel and keeping their Bodies warm'. John Wesley ( 1747 ) recommended a spartan treatment for his patients: nevertheless he advised for 'an habitual Cholick to wear a thin soft Flannel on the part'.

During the long period of overdressing, infants, perhaps, suffered most from the attempts to maintain the cutaneous transpiration at all costs. William Cadogan ( 1748 ) complained that 'the first Mistake is that they think the new born Infant cannot be kept too warm; from this Prejudice they load and bind it with Flannel, Wrappers, Stays, etc. commonly called Cloaths, which all together are equal to its own weight'. John Pringle, writing on his experiences in the campaigns of $1742-50$, said: 'The Experience we have had of the use of Under-Waistcoats during the Winter Campaigns should teach us to make the same Provision for the Army in any future War. None of the foreign Soldiers are without this necessary part of the Cloathing and indeed no Man of the meanest Condition abroad. The Nature and cause of Dysentery,' continued Pringle, 'is abounding and corrupted Bile. . . . The Infection is evidently communicated by the Faeces of those who are ill from the Distemper.' This last remark precedes by a full century the discovery of John Snow that cholera (like some forms of dysentery) is a water-borne disease. A similar complaint about the lack of

* From the time of Sanctorius and until the end of the nineteenth century the word 'perspiration' ('matter of perspiration', 'perspirable matter') was to mean not the visible liquid sweat but the insensible perspiration from skin and lungs. This aspect of the subject will be dealt with in a later article to be published in this Journal. 


\section{The History of the Flannel Binder and Cholera Belt}

waistcoats was made by John Chandler ( $176 \mathrm{I}$ ). 'The French and Italians', he insisted, 'have their Under-Waistcoats; the Dutch are well known to multiply them occasionally, as their Country, like ours, is subject to much Fog and damp cold Weather. What sufficient Reason can be given why the English of all Nations should be . . . so superior, as they often are, to all admonitions, from Instincts; from Prudence and the Example of others?' Colombier ( 1772 ) was concerned about the use of wool for French soldiers. 'It is a bad thing for the clothing of soldiers to be made of wool,' said he, 'for it has several disadvantages, such as easily retaining miasms floating in the air, and drying with difficulty; and finally of imbibing sweat which then corrupts and gives out putrid and dangerous vapours.'

In connection with suggestions made a century later concerning the protective effect on the abdomen of high trousers, the following Regimental Record of 1776 may be noted: 'Directions of the Acting Commander in Chief who thought proper to diminish the quantity of necessaries. Two pairs of breeches made full, to come up upon the belly, and to cover the knees.' Maurice, Count de Saxe, Marshal of the French Armies, had great interest in the hygiene of the soldier. 'In regard to his clothing,' said the Count, 'he should have a waistcoat with a small one under it in the nature of a small doublet. Almost all German Cavalry are clothed in this manner.'

Preoccupation with the effect of miasms may have led Gilbert Blane to make the following observation ( 1785 ): 'May not the cloathing be considered as a filter, as it were, to separate the impurities of the air before it comes in contact with the surface of the body, and therefore sudden and unreasonable change of apparel be very unsafe to health?' Benjamin Moseley ( 1787 ), a practitioner in the West Indies, was a great believer in wool. 'Flannel is warmth without encumbrance,' said he, 'and it acts as a friction to the skin and keeps the pores open; it also creates a uniform atmosphere around the body . . . that perspiration may not be suddenly checked and the body may cool gradually.' John Hunter ( 1788 ) Superintendent of Military Hospitals in Jamaica, held similar views.

Benjamin Rush (I789) said that during the war in America, General Gage obliged his soldiers to wear flannel shirts from an accidental want of linen; and, added Rush, 'not a single soldier belonging to that Regiment was ever in the Military Hospitals'. At this time appeared an essay on 'Clothing' by Walter Vaughan, English country practitioner. 'There is no luxury;' he noted, 'greater than that of wearing flannel when once used to it . . . but why is linen preferred to flannel? I am told that it is because flannel heats more than Linen or Cotton. As to the Benefit derived from Flannel as an Electric, I cannot conveniently enlarge upon it. It is said that Flannel always weakens, especially when worn next the Skin. This is a first Objection and a more unfounded one there cannot be; hence some people avoid it as 


\section{E. T. Renbourn}

they would a large dose of Dover's Powder. They say Flannel may cause an Eruption, but I deny it ever can. Another Objection is that it disposes to Morbus Pedicularis, but this is only made by those who use a flannel Waistcoat to serve for several Months.' The eruption bespoken by Vaughan was undoubtedly prickly heat. Periodically in the literature we hear of such complaints concerning woollen garments, particularly in the tropics.

William Lempriere ( 1797 ), apothecary to His Majesty's Force in Jamaica, noted that the soldiers were provided with two flannel shirts. In order to prevent men selling this important item of their necessaries, a day was appointed during the week for reviewing them. 'At that time,' said he, 'I thought Flannel highly beneficial under every Circumstance in the West Indies; further experience induces me to think that Flannel should be reserved for active Service.'

\section{THE GHILLED ABDOMEN. GUMMERBUNDS AND FLANNEL BELTS, EARLY NINETEENTH GENTURY}

Up to the end of the eighteenth century the humoral theory and the doctrine of obstructed 'perspiration' was still firmly established. The fear of chilling applied to the whole body, and only at the end of the century does one come across specific reference to chilling of the abdomen and its effect on the bowel by contiguous sympathy. This may explain the changing emphasis from long flannel shirts and waistcoats to abdominal bandages, binders and belts.

We now turn to two medical men who served in the Egyptian campaign of r8or. Dewar laid much stress on the value of swathing the abdomen with flannel bandages in the treatment of dysentery. Sir James McGrigor, colleague of Wellington, Superintendent Surgeon of the East India Company's army in Egypt and later Director-General of the Army Medical Department, said 'we had trial of a mode of treatment which was strongly recommended by Dr. Whyte in I 799. It was the application of a flannel bandage to the whole abdomen. However, in cases of either European or Tropical Dysentery, I would not rely on it alone for a cure.' Although there is a long history of the use of flannel garments, the above would appear to be early specific references to its use as a bandage or binder in the prevention or treatment of diarrhoea and dysentery. Thomas Winterbottom, physician to the British Colony at Free Town, Sierra Leone, wrote as follows in 1803: 'The use of flannel next the skin cannot be too strongly recommended, for although the first wearing of it may produce some trifling inconvenience such as itching of the skin and an increased eruption of prickly heat, this seldom lasts more than a few days.'

At the turn of the new century, ideas on the nature of cholera were no 


\section{The History of the Flannel Binder and Cholera Belt}

more advanced than they had been in the time of the ancient Greeks or Romans. Buchan (1807) said that the disease was occasioned by 'a redundancy and putrid acrimony of the bile, cold, and food that easily turns rancid or sour in the stomach. . . . It may likewise proceed from violent passions or affections of the mind. . . . They ought likewise to beware of cold, moisture or whatever else obstructs the perspiration and should wear flannel next the skin.' Most standard books wrote similarly on diarrhoea, dysentery or cholera.

James Johnson (1813) was not convinced about the value of flannel, 'for,' he said, 'it was too heavy, too slow a conductor of heat and its spicules increased the perspiratory action of the body'. Too frequent laundering was a bad thing, 'for where it becomes wet through in a few hours of perspiration, it should not be consigned to the wash, but carefully dried and worn again. It is astonishing how much less exhausting is clothing which has been impregnated with perspiration.' No proof was, however; offered for this strange suggestion. 'The turban and cummerband', he continued, 'meet our eye at every step; the former to defend the head from the direct rays of a powerful sun; the latter, apparently, for the purpose of preserving the important viscera of the abdomen from the deleterious effects of cold. A fine shawl round the waist forms an excellent cummerband, and should never be neglected . . . especially by those whose bowels are in any degree tender.' Johnson, however, did not specifically mention the use of belts or binders. Robert Jackson ( 18 I 7), surgeon to the Buffs, was, like Pringle, a reformer of hygiene, and preceded Currie in the use of the cold régime in fevers. For the dysenteries of Jamaica he advised the application of 'flannel over the abdomen, adding such pressure to it by a flannel roller as gives support to the interior parts'.

The Manual (1819) of James Millingen was a ponderous book, but it put forward valuable innovations, one of which was the setting up of an Army Medical School in England. Discussing the value of belts, sashes and girdles for the soldier, he noted that 'they afford support, prevent rupture, check bowel complaints and facilitate exercise, particularly in warm weather. Hence most inhabitants of Southern or Eastern countries wear them.' Like most observers on clothing, he was here confusing the demands of fashion and tradition with hygienic considerations.

In the same year appeared Bampfield's Tropical Dysentery, a book that was to remain a standard text for many years. 'The copious perspiration of the newly arrived Europeans,' said Bampfield, 'becomes accumulated more especially on that part of the abdomen where the waist band of the small clothes or pantaloons presses against it, the tight or close application of which occasions an increase of heat and perspiration . . . hence, if he should lie down, cold will be induced in this particular part of the abdomen by the 


\section{E. T. Renbourn}

evaporation of the exhaled fluid from the wet linen in contact with it. Perspiration, before profuse, will now be effectually suppressed with injurious effects felt in the chylopoietic viscera.' It is not clear whether Bampfield was referring to obstruction of the insensible perspiration or to the suppression of sweat occurring in heat-stroke-a condition which may, on occasion, present itself as diarrhoea.

James Annesley, of the Madras Medical Establishment, was yet another reformer of tropical hygiene. His Researches ( 1828 ) in two volumes was almost encyclopaedic in compass. 'The use of a thick flannel banyan and cummerband during the Monsoon will,' he said, 'exert considerable influence in preventing bowel complaints, one great source of mortality amongst Europeans in India. The cummerband or waist belt is of the greatest use to soldiers and convalescents generally; but care must be taken that it should form a good support to the bowels and be sufficiently broad to embrace the whole abdomen from the Os Ilium to the ribs; and not be, as is too frequently the case, a narrow band acting as a ligature around the abdomen.' Annesley, like Colombier and others, was suspicious of retained sweat. 'It has been repeatedly proved', he continued, 'that substances fabricated of silk, wool or even cotton and flax, repeatedly exposed to marshy exhalations, will rapidly undergo decay ... and swarm with maggots and worms.' Sanctorius wrote similarly in 1614 .

\section{THE GHILLED ABDOMEN. THE GHOLERA BELT, EARLY NINETEENTH GENTURY}

Cholera was an ancient disease in India, but it was not till 1817 that epidemics began to spread by land routes out of the country. During the years $1823-30$ the disease appeared in Persia, reaching Astrakhan and Moscow in 1830 , and was noted in Hamburg and Sunderland by 1831. Fear and consternation rapidly spread over Europe. During I83o English military observers present at the uprising of the Polish patriots in Warsaw, sent back news of the local measures taken to confine the disease. Reports soon appeared in the Cholera Gazette. The impression is gathered that the use of a flannel belt, as prophylaxis against cholera, originated in the Polish Rebellion. However, the flannel waistcoast, belt and roller had long been in use by soldiers and others both in Europe and in the tropics. According to Forbes, British soldiers, in 1831 , were ordered to wear (and pay for) a flannel belt. Combe, writing of the period, said: 'In the Army and Navy, accordingly, where practical experience is most followed, the utmost attention is now paid to enforcing the use of flannel as a protection against fever, dysentery and other diseases, particularly in unhealthy climates.' Combe did not use the expression 'cholera belt'. 


\section{The History of the Flannel Binder and Cholera Belt}

The Catechism of Health by Granville was written at the time of the 1831 epidemic and is hence of interest in the search for the earliest use of the expression 'cholera belt'. Talking of preventive measures, Granville said that 'the first is to wear a large piece of flannel next the skin over the belly by day; not because there is any specific virtue in this device, but because that part of the body more especially should be kept warm. If the surface of the abdomen feels cold to the touch when you get into bed or awake at night, apply hot cloths or flannels to it immediately.' The above is, perhaps, an early reference to the fact that the flannel bandage was in no way a specific preventive or cure for cholera. McGrigor had made a similar remark concerning flannel belts and dysentery a quarter of a century earlier. It does not appear that Granville used the expression 'cholera belt'.

Flannel belts were at this time in general use for the prevention of cholera. In France, Desruelles ( 1831 ) wrote on the precautions to be taken in times of epidemic. 'One must wear a flannel waistcoat or woollen belt,' he said, 'to keep the body at a comfortable heat . . . and not to suddenly cool the skin when the body is covered in sweat.' The text-book on dysentery and hepatitis by Parkes appeared in 1846 , but no specific mention can be found of a 'cholera belt'. From 1832 until 1848 some hundreds of articles on various aspects of cholera appeared, but cursory examination of these does not show the use of the expression 'cholera belt', although it is pretty certain that the term was being used fairly widely by the populace in general.

In 1848 there was published Instructions to Army Medical Officers for their Guidance on the Appearance of the Spasmodic Cholera. Under item 15, we note that 'each soldier is to be provided with two cholera belts, as part of his Necessaries. Flannel waistcoats, if thought necessary for individuals, are to be provided at their own expense.' Here at last is an early official reference to the 'cholera belt'!

In the same year Thomas Allen enjoined his readers to 'let a flannel or woollen belt be worn round the belly. This has been serviceable in checking a tendency to bowel complaints so common during the prevalence of cholera. Writing on cholera in 1848, Sir James Murray advised that 'energetic friction, not with a harsh brush but a warm flannel, will go far to keep the body charged with good vital atomic equivalents of electricity'. The significance of this statement is best left to the imagination of the reader! In 1849 a pamphlet (price $2 d$.) appeared with the following title'What has Cholera done in London?' The anonymous author advised his readers to wear a folded flannel belt around the belly and outside a cotton vest, adding, 'this is better than wearing flannel all over the body as recommended by the Board of Health'. The work of John Snow in 1849 proved fairly conclusively that cholera was a water-borne disease, and thus substantiated the theory put forward by Pringle almost a century before. 


\section{E. T. Renbourn}

\section{THE GHILLED ABDOMEN. THE GHOLERA BELT, SECOND HALF OF NINETEENTH GENTURY}

According to Parkes, cholera belts were amongst the extra clothing issued to troops in the Crimea. After the death of James Johnson, Martin reedited their text-book on tropical medicine. In the new edition of 1856 , he wrote: 'The Kummerbund is certainly a most valuable part of the dress, and one that is extensively imitated throughout India by Europeans in the form of a cotton or flannel waistband worn generally next the skin.' William Aitken, Professor of Pathology at the new Army Medical School and an experienced tropical practitioner, wrote similarly two years later. Julius Jeffreys of the Indian Army (1858) believed that not only did the sun's rays penetrate the head and spine but also the abdomen, and suggested a 'metallized abdominal curtain' as protection. At the time of the 'Royal Commission' of $185^{8}$ Sidney Herbert asked if soldiers wore flannel waistcoats under the flannel or cotton shirts. He was told that the practice was not general. It was further pointed out that a flannel shirt was more expensive than one of cotton, was difficult to wash, but gave longer wear. By I86 I Martin had somewhat modified his previous remarks on abdominal protection. 'With two flannel shirts sufficiently long to cover the entire trunk, the wearer need not be hampered with cholera belts, for he will be supplied with enough warmth and cleanliness.' John Davy (1862) noted that: 'In most warm climates, especially in South Europe and the warmer regions of Asia, a sash forms a part of the dress of the natives; and the swathing of the loins is a preparation for the journey. In the first voyage I made to the Mediterranean, I made companion of a merchant who never left England for Egypt without adopting the Eastern precaution. I think, he believed he escaped bowel complaints. In the battle field, in case of bleeding from a wound, a sash would form an excellent bandage.'

Moore (1862), like Blane, believed that body coverings could act as a filter of miasms. 'There are', said he, 'facts tending to prove that the body well wrapped in flannel or clad in warm clothing so as to prevent a check to the perspiration and chill from the night air, is more capable of resisting malaria, inflammation of the liver or kidneys.' Moore also believed that a cummerbund kept the solar rays off the spine and hence gave protection against sunstroke.

In 1862 the following Order was published in Simla, India: 'Men will ... invariably wear flannel belts and all precautions must be taken to prevent them remaining in damp clothes.' The official clothing 'Regulations' for I 865 show two separate items of interest: viz., 'Belts, cholera, for wear in summer weather', and 'Belts, flannel, for East India, China, Ceylon and Mauritius'. The difference between them must have been small; the price 


\section{The History of the Flannel Binder and Cholera Belt}

was identical. Cholera belts were not issued in the New Zealand campaign of $1863-5$. In the second edition of his Hygiene, Parkes added: 'drawers folding over the abdomen form with the long shirt a double fold of flannel ... and the necessity for cholera belts or cummerbands is avoided'.

The O'Byrnes 'Army Circulars' refer to an 'Order' of 1867: 'Should an outbreak of Cholera or other disease at a Foreign Station render it advisable that Cholera Belts be temporarily worn, the officer in command ... may authorize the issue from the Military Store of two Cholera Belts to each soldier; ... unnecessary belts should be returned . . . for re-issue. A charge of one shilling will be made for every cholera belt lost or destroyed.' Gordon, in 1873 , wrote on his experiences as medical observer in the Franco-Prussian War. 'The clothing of the French soldier', he noted, 'was a Norfolk jacket, loose so as to admit a waistcoat or cummerband round the loins. Girdles, waist-belts or cummerbands were worn during the siege of Paris by all contingent forces. . . . Each German soldier was provided with two flannel shirts and besides these two flannel body belts.' Cholera belts were issued in the Sunjhie-ujong expedition of 1874 and the following year in Malaya. The hygienists Roth and Lex (1877) pointed out that body belts (Leibbinde) were not an issue in the German Army as they were in the Austrian and English Armies. In the Jowaki expedition of 1877 , cholera belts were again issued to soldiers. New clothing 'Regulations' appeared in $188 \mathrm{I}$, but the reference to cholera belts was not appreciably different from that of 1865 .

Jousset (1884) referred to the issue of flannel belts to the French Navy as a new innovation. Their value, he said, was to check suppression of insensible perspiration and hence prevent bronchitis, rheumatism and abdominal flux. In the same year, two other Frenchmen, Dastre and Morat, demonstrated an inverse relationship between the cutaneous and splanchnic blood-vessels. This would have made an excellent explanation of the sympathy (contiguous or continuous) between skin and bowel and suggested that there was no direct chilling of the intestine. Unfortunately the new work did not find its way into the clinical literature.

In I888 Andrew Duncan, surgeon in the Bengal Army, wrote on the cholera belt as follows: 'Dr. Veale says that it has never been proved to protect from tropical diseases . . . and soldiers are unable to endure long marches, and fall victims to sunstroke, ardent fever and cardiac failure.' Duncan's own opinion was, however, quite different. 'Cholera belts must be stringently insisted on,' he commanded, 'and there should be periodic inspection - and without warning - to see that men are wearing them. . . . The waistcoat was worn in Algeria by the French Army with much benefit. In the Looshai expedition, the 42 H.L.I. was unprovided with flannel belts, and as a consequence there was an excess prevalence of bowel disorders.' 


\section{E. T. Renbourn}

Duncan's strategem for surprising the unfortunate soldier without a belt is reminiscent of that used by Lempriere some ninety years before.

Lane Notter (1893) pointed out that the most rational garment for abdominal protection was the 'combination' which, falling loosely over the abdomen, avoided the excess formation of sweat which Bampfield regarded as being so dangerous. New official 'Regulations' appeared in I894, but the Instructions on cholera remained unchanged.

\section{THE GHILLED ABDOMEN. THE FLANNEL AND GHOLERA BELT, TWENTIETH GENTURY}

Looking back on the literature of the nineteenth century one finds waxing and waning enthusiasms for flannel binders and cholera belts, and this was sometimes related to fear of a cholera epidemic. The argument put forward on behalf of flannel was that it prevented suppression of 'perspiration' and the consequent flow of blocked excretions to the bowel; and the case for a belt in particular was the contiguous sympathy between the abdominal wall and the underlying viscera. However, few, if any, clinicians seriously entertained the idea that dysentery or cholera could, in fact, be prevented by simply wearing a flannel belt, particularly after Koch, by isolating the Vibrio Cholerae, proved the contention of Pringle that the stools were infective and that of Snow concerning contamination of drinking water.

In Igor Major Munson of the American Army noted that next to the head it was the abdomen which, in the tropics, required protection. 'This, in our service, is well afforded by flannel shirt and drawers worn by the soldier, and hence recourse to the abdominal bandage held in such esteem in the British and French Colonial Service is unnecessary. . . . To march on a hot day with such a band over the abdomen is evidently illogical, since it increases the temperature and weakens the power of resistance and thus, perhaps, even predisposes to diarrhoea.' Parkes and Veale had already said the same many years before. In his Hints for Tropical Climates (1903) Harford pointed out the value of belts made of 'Wolsey' or 'Jaeger' wool. 'Petanelle', he added, had the antiseptic and deodorant properties of peat fibre and was hence particularly suitable for the purpose. With Munson and others he stressed the value of high trousers for protecting the abdomen from chill. Since I 775 this matter was constantly referred to in the English literature. Whether its use was usually a matter of hygiene or a trend in fashion must be left to the tailor.

Whilst accepting chemical and bacterial irritants as causes of dysentery, Giles (1904) still believed that in the tropics the commonest cause was 'the peculiar treacherous chill that precedes the dawn'. He was against the use 


\section{The History of the Flannel Binder and Cholera Belt}

of body belts because of the tendency to ruck up, to become uncomfortable and constitute a useless cover for the abdomen. After a short period of habituation, he said, 'deprivation conveys a distinct sensation of discomfort' -a statement frequently found in the literature from Wainewright ( 1 707) onwards. Simpson, in 1905, advocated the use of Jaeger belts and advised a fresh one for the night. To prevent slipping (which it undoubtedly always did) he suggested attaching it to the pyjamas or other night clothing.

The official Manual of Sanitation (1907) still recommended a flannel belt for preventing diarrhoea and dysentery. The clothing 'Regulations' of 1907-9 mentioned flannel and woollen belts, but the term 'cholera belt' had disappeared. The expression was now rarely to be found even in medical dictionaries. Firth in his Military Hygiene was undecided on the value of flannel belts, but insisted that 'if once worn they must be continued ... as the chance of chill and consequent enteritis is much increased'. 'Regulations' of I9I I still referred to the two types of belt, but this appears to be the last official mention of abdominal belts for general issue by the British Army.

Disagreement, even between experts, continued. Hehir (I9I I), writing of his experiences in India and 'at the risk of being considered old fashioned', strongly recommended the flannel belt as an indispensable item of kit for the soldier, adding that it cost only a few annas, weighed only a few ounces, lasted for a whole campaign and was quickly washed and dried. In the same year, Sir Pardey Lukis, an equally experienced tropical practitioner, said the belt failed to answer its purpose and after exercise became ' $a$ wet poultice over the abdomen'.

At the commencement of the First World War, Colonel Havard of the American Army said the flannel band had little or no use day or night, and in any case the triangular apron of Wanhill was preferable. Major Ashburn (1915), another American, stressed that since diarrhoea was infectious there could be no object in using a flannel belt. Furthermore, he added, 'the discomfort produced by too great warmth of the body, exercise, perspiration and prickly heat were hardly likely to offer additional protection over good general hygiene'. It may be added that American army hygienists had always been circumspect in their attitude to the clothing and equipment of the soldier, and the topé, spine pad and cholera belt of the British Army had never found favour with them as they had on the Continent.

The official clothing 'Regulations' of I9I4 and I9I 7 no longer mentioned belts, either flannel or woollen. A number of army hygienists reported on them very unfavourably at this period, but they were nevertheless introduced into the British Army in France during the winter of 1917 on account of the warmth they apparently afforded. The width of the army puttee made this item a useful wide bandage, and there is evidence that when flannel belts were in short supply the puttee was used as an improvised 


\section{E. T. Renbourn}

abdominal binder. The official Medical History of the War noted that 'there was a unanimity of opinion that body bands did not contribute either to comfort, warmth or health, and soldiers themselves disliked wearing bands as they harboured vermin. Ultimately . . . their issue ceased.' These remarks on the verminous nature of garments worn for long periods had been preceded by those of Sanctorius, Vaughan, Annesley and others.

After the First World War this experience was forgotten. As late as 1919 Castellani and Chalmers noted that abdominal belts-'so called cholera belts'-were much abused, but still urged their value 'to people with a tendency to internal disorders'. Even at this late date it was tacitly assumed that some ill-defined physiological relationship existed between the skin and the bowel, but no reference was made to the 'Law of Dastre and Morat'.

There is little value in recording in detail the opinion existing between the two world wars. Most British tropical hygienists were still in favour of the use of a flannel belt for the prevention of bowel complaints, but this item received no mention in the clothing 'Regulations' of 1922 or 1936.

During the Second World War, Stenning came to the conclusion that chilling of the abdomen and salt deficiency were factors to be considered in the development of tropical diarrhoea. Napier, writing in 1946, said the power of the flannel cholera belt was mythical, and noted (as did Vaughan and Winterbottom and others long before him) that it could be guaranteed to produce 'a nice band of prickly heat in most climates'. However, the value of a flannel belt was brought up again by Kershaw in the following year. Manson-Bahr in I950 noted that 'modern opinion, although it condemns the woollen belt during the day, considers it indispensable while sleeping near a draught. A belt or broad binder or a towel is preferred round the waist.' In 1952 the following appeared in the text-book of Rogers and Megaw: 'Attacks of diarrhoea are often associated with chill of the abdomen especially at night when a light blanket or shawl should be wrapped round abdomen and chest.'

In the British Army, only the Chelsea Pensioners are now supplied with a flannel belt. Colonial troops of some continental armies still wear the cummerbund, and the present German Army is issued with a knitted woollen body belt introduced between the two world wars, apparently for the protection of the bowels and kidneys. A cycle of a century and a half has been completed. The wheel of hygienic fashion may be about to move again.

\section{EPILOGUE}

It has long been accepted that chilling of the body with resulting reflex vasomotor phenomena is a factor to be considered in a number of clinical 


\section{The History of the Flannel Binder and Cholera Belt}

disorders, but it is now doubted whether such a mechanism plays a role in rheumatic disorders, pneumonia or nephritis. There is at present little data on the physiological relationship between skin and bowel, and the flannel belt has never, in its long history, been put out to scientific trial. Although there is some confirmation of the old 'Law of Dastre and Morat', heating or chilling of the abdominal wall produces no obvious changes in lower bowel temperature. It has been suggested that climate may modify the bacterial flora of the bowel and in this way presumably affect its activity. However, there is little evidence that any harm overcame the large number of soldiers who, during the last war, dispensed with the time-honoured spine pad, topé or flannel belt in a tropical climate.

In biblical times and classical periods the emotions were often believed to have their seat in the abdominal region, and man 'yearned with his bowels'. The loins were the supposed seat of strength and generative powers; yet lacked the cage-like support afforded to the chest. During his chequered career and during his infancy man has been preoccupied with his alimentary canal; and, for some, it still remains an organ of emotional expression. It may be that, in the subconscious mind, the flannel belt has become symbolic of duty, of a tight rein over the basic instincts, and of protection from a hostile environment. For these reasons it is, perhaps, not surprising that he has found comfort of mind and allayed the hungers of his body by support given to his abdominal viscera.

Rings and belts have, in the past, been associated with the magical qualities of 'tightness' and invisibility. Saint Guthlac cast out devils by buckling his belt round a possessed man. These are, perhaps, other reasons why the body belt remains, albeit disguised, in the male corset and the so-called magnetic or electric belt.

For a century and a half or more, man accepted the 'ligature round his abdomen', the discomforts of prickly heat and even the presence of vermin as the price to be paid for the doubtful virtues of a warm belly. Perhaps future work will show that, in the susceptible individual, a sympathy does exist between the chilled abdomen and an increased activity of the intestinal canal. But for those hygienists still prepared to advise a flannel binder or a cholera belt, these pages are offered for consideration.

\section{ACKNOWLEDGEMENTS}

I am greatly indebted to Dr. F. N. L. Poynter, and the staff of the Wellcome Historical Medical Library. Mr. D. W. King, of the War Office Library, and Mr. M. Davies, of the Royal Army Medical College Library, gave valuable assistance in the search for official documents. 


\section{E. T. Renbourn}

\section{REFERENCES}

Aitken, W. (1858). The Science and Practice of Medicine. Glasgow.

Allen, T. (1848). Plain Regulations for the Prevention and Treatment of Cholera. London.

Annesley, J. (1828). Researches into the Causes, Nature and Treatment of the Diseases of India. London.

Anon. (1849). What has Cholera Done in London? A Few Words of Warning for the Wicked Man. London.

Ash B URN, P. M. (1915). The Elements of Military Hygiene for Officers of the Line. Boston.

Bampfield, R. W. (1819). A Practical Treatise on Tropical Dysentery. London.

Blane, G. (1785). Observations on the Diseases Incident to Seamen. London.

Buchan, W. (1807). Buchan's Domestic Medicine Modernised. London.

Gadogan, W. (1748). An Essay upon the Nursing and Management of Children. London.

Castellani, A., and Ghalmers, A. J. (1919). Manual of Tropical Medicine. 3rd ed.

London.

Ghandere, J. (176r). A Treatise of the Disease called a Cold. London.

Golombier, J. (1772). Code de Médecine Militaire pour le Service de Terre. Paris.

Сомв E, A. (1834). The Principles of Physiology Applied to the Preservation of Health. Edinburgh.

Dastre, A., and Morat, J. P. (1884). Recherches Expérimentales sur le Système Nerveux

Vasomoteur. Paris.

Davy, J. (1862). On Some of the More Important Diseases of the Army. London.

Desruelles, H. M. J. (1931). Précis Physiologique du Cholera-Morbus. Paris.

Dew A R, H. (1802). Observations on Diarrhoea and Dysentery in the British Army in Egypt, I8oI.

London.

Duncan, A. (1888). The Prevention of Disease in Tropical and Sub-Tropical Countries. London.

FIRTH, R. H. (1908). Text Book of Military Hygiene. London.

Forbes, A. (1929). A History of the Army Ordnance Service. London.

Giles, G. M. (1904). Climate and Health in Hot Countries, etc. London.

GORD ON, C. A. (1873). Lessons on Hygiene and Surgery from the Franco-Prussian War. London.

Granville, A. B. (1831). The Catechism of Health. London.

HARFORD, G. F. (1903). Hints on Outfits for Travellers in Tropical Countries. London.

HA VARD, V. (1914). Manual of Military Hygiene. London.

He hir, P. (IgI I). Prevention of Diseases and Inefficiency with Special Reference to Indian Frontier Warfare. Allahabad.

Hunte R, J. ( 1788 ). Observations on Diseases of the Army in Famaica. London.

JAGKson, R. (1817). History and Cure of Febrile Diseases in the West Indies. London.

JEFFREYS, W. (1858). The British Army in India, etc. London.

Joнnson, J. (1813). The Influence of Tropical Climates ... on European Constitutions. London.

Johnson, J., and Martin, J. R. (1856). The Influence of Tropical Climates, etc. 6th ed.

London.

Jouss e t, A. (1884). Traité de l'Acclimatement et de l'Acclimatation. Paris.

KeRshaW, G. R. (1947). Brit. med. J., I, 7 I 7 .

Lempriere, W. (1 797). Practical Observations on Diseases of Famaica. London.

Lukis, G. P., and BlaGkham, R. J. (1911). Tropical Hygiene for Anglo-Indians and Indians. Calcutta.

MGGrigor, J. (1804). Medical Sketches of the Expedition to Egypt. London.

Manson-Bahr, P. H. (1950). Manson's Tropical Diseases. 1 $3^{\text {th }}$ ed. London.

Martin, J. R. (1861). The Influence of Tropical Climates in Producing the Acute Endemic Diseases of Europeans. 2nd ed. London. 


\section{The History of the Flannel Binder and Cholera Belt}

Millingen, J. G. (1819). The Amy Medical Officer's Manuial upon Active Service. London. Moore, W. J. (1862). A Manual of Diseases of India. London.

Moseley, B. ( 1787 ). A Treatise on Tropical Diseases. London.

Munson, E. L. (1901). The Theory and Practice of Military Hygiene. New York.

Murray, J. (1848). Lancet, 2, 445.

Napie R, L. E. (1946). Principles of Tropical Medicine. London.

Notter, J. L. (1893) \& Davidson, A. Hygiene and Diseases of Warm Climates. London. O'Byrnes (1877). Collection of Army Circulars and General Orders, 1867-1876. War Office.

PARKes, E. A. (1846). Remarks on the Dysentery and Hepatitis of India. London.

- (1864). A Manual of Practical Hygiene ... for Use in the Medical Services of the Army. London.

Pringle, J. (1752). Observations on Diseases of the Army. London.

Quincy, J. (I 720). See Sanctorius, S.

Rogers, L. \& Megaw, J. W. D. (1952). Tropical Medicine. London.

Rotr, W., and LEX, R. (1877). Handbuch der Militär-Gesundheitspflege. Berlin.

Rush, B. (1 789-98). Medical Enquiries and Observations. Philadelphia.

San ctorius, S. ( 720 ). Medicina Statica. Translated into. English by J. Quincy. London.

SAXE, M. DE (1776). Reveries or Memories of the Art of War. Edinburgh.

Simpson, W. J. R. (1905): The Maintenance of Health in the Tropics. London.

Snow, J. (1849). On the Mode of Communication of Cholera. London.

Stenning, J. C. (1945). 7. Roy. nav. med. Sero., 31, 129.

Towne, R. (1 726). A Treatise on the Diseases Most Frequent in the West Indies. London.

Vaughan, W. (1792). An Essay Philosophical and Medical Concerning Modern Clothing. Rochester.

WaINe Wright, J. (1707). An Experimental Account of the Non-Naturals. London.

Wesley, J. (1 747). Primitive Physick. Bristol.

Winterb OtTam, T. M. (1803). Medical Directions for the Use of Navigators and Settlers in Hot Climates. London. 